\title{
Evaluation of a Carbonic Anhydrase IX-Targeted Near-Infrared Dye for Fluorescence-Guided Surgery of Hypoxic Tumors
}

\author{
Peng-Cheng Lv ${ }^{a, b}$, Jyoti Roy ${ }^{a, b}$, Karson S. Putt ${ }^{a}$, and Philip S. Low ${ }^{a, b}$ \\ aCenter for Drug Discovery, Purdue University, West Lafayette IN 47907 USA \\ bDepartment of Chemistry, Purdue University, West Lafayette IN 47907 USA
}

\begin{abstract}
Proof-of-principle studies in ovarian, lung and brain cancer patients have shown that fluorescenceguided surgery can enable removal of otherwise undetectable malignant lesions, decrease the number of cancer-positive margins, and permit identification of disease-containing lymph nodes that would have normally evaded resection. Unfortunately, the current arsenal of tumor-targeted fluorescent dyes does not permit identification of all cancers, raising the need to design new tumor-specific fluorescent dyes to illuminate the currently undetectable cancers. In an effort to design a more universal fluorescent cancer imaging agent, we have undertaken to synthesize a fluorophore that could label all hypoxic regions of tumors. We report here the synthesis, in vitro binding and in vivo imaging of a near infrared (NIR) fluorescent dye that is targeted to carbonic anhydrase IX (CA IX), i.e. a widely accepted marker of hypoxic tissues. The low molecular weight NIR probe, named Hypoxyfluor, is shown to bind CA IX with high affinity and accumulate rapidly and selectively in CA IX positive tumors. Because nearly all human cancers contain hypoxic regions that express CA IX abundantly, this NIR probe should facilitate surgical resection of a wide variety of solid tumors.
\end{abstract}

\section{Graphical abstract}

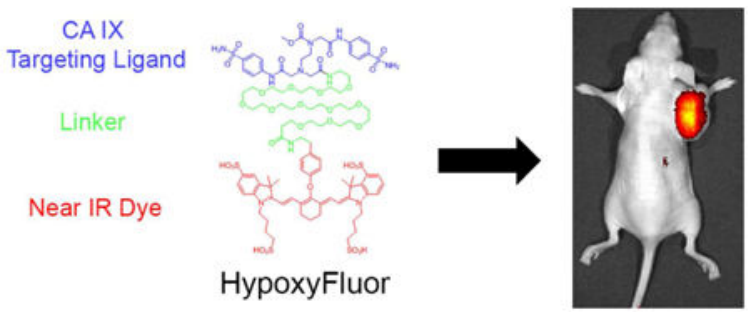

\section{Keywords}

Hypoxia; Carbonic anhydrase IX; CA IX; Fluorescence-guided surgery

\footnotetext{
*Author to whom all correspondence should be addressed: Philip S. Low, plow @ purdue.edu, Phone: 765-494-5272, Department of Chemistry, Purdue University, 560 Oval Drive, West Lafayette IN 47907.

Supporting Information: Chemical characterization of synthesis intermediates, physiochemical properties of Hypoxyfluor and representative whole animal imaging 8 hours post-injection can be viewed in the supporting information. The supporting information is available free of charge on the ACS Publication website.
} 


\section{Introduction}

Solid tumors commonly contain regions of sustained hypoxia due to an inadequate blood supply and/or malformed vasculature $(1,2,3,4)$. This hypoxia induces activation of powerful transcription factors that lead to marked changes in gene expression, reprogramming of cancer cell differentiation, acceleration of malignant progression, and alterations in responses to therapies $(2,3,4,5)$. Included among the global adaptations to hypoxia are significant changes in cell surface markers that are frequently used for tumor detection, identification and visualization. Reduction in tumor marker expression can be harmful if it leads to a failure to detect or remove malignant disease. Gain in tumor-specific protein expression can be beneficial if it allows better detection or visualization of otherwise undetectable regions of tumors.

Carbonic anhydrase IX (CA IX) constitutes a potentially valuable tumor marker, because i) its functional expression in normal tissues is primarily limited to the kidneys, ii) its substrate binding site is oriented on the exoplasmic surface of cells, iii) it constitutively endocytoses in cancer cells and carries with it any attached cargo, and iv) it is upregulated up to 150 fold in many human cancers $(6,7)$. Included among the cancers that over-express CA IX are malignancies of the bladder $(8,9)$, brain $(10,11,12)$, breast $(13,14,15,16,17)$, cervix $(18,19,20,21)$, colorectum $(22,23,24)$, stomach $(25)$, head \& neck $(26,27,28)$, lung $(29,30,31)$, ovary (32) and pancreas (33). Additionally, due to a common mutation in the VHL gene that leads to constitutive HIF-1a activation, normoxic clear cell carcinomas of the kidney are found to upregulate CA IX $(34,35,36)$. Not surprisingly, with its restricted expression in normal tissues and over-expression in many tumors, CA IX has been repeatedly touted as an excellent target for specific delivery of both imaging and therapeutic agents to solid tumors $(6,37,38)$.

One emerging application of tumor-specific targeting ligands involves the tumor-selective delivery of highly fluorescent near infrared (NIR) dyes to facilitate the identification and resection of malignant lesions during surgery. For example, folate targeted NIR dyes have been used in both murine tumor models (39) and human patients (40) to visualize and excise tumors. In fact, the use of fluorescence-guided surgery in clinical trials has enabled detection of malignant lesions that were not otherwise detected in lung adenocarcinomas (40), hepatocellular carcinomas (41), pancreatic cancers (42) and colorectal cancers (43), potentially preventing corrective surgeries and associated morbidities. Because more thorough removal of malignant disease is also commonly correlated with improved patient outcome $(44,45)$, use of tumor-targeted fluorescent dyes to enhance cancer removal has the potential to change the practice of cancer surgery.

Encouraged by the success of folate-fluorescent dye conjugates $(39,40,41,42,43)$, we undertook to develop a carbonic anhydrase IX targeted near infrared dye to expand the ability of surgeons to locate and resect solid tumors. In this paper, we describe the synthesis, in vitro testing and in vivo evaluation of a novel CA IX-targeted cyanine dye. We demonstrate that Hypoxyfluor binds specifically to CA IX expressing cancer cells and enables their sensitive detection in mice bearing human tumor xenografts. 


\section{Materials and methods}

\section{Materials}

2-(1H-7-Azabenzotriazole-1-yl)-1,1,3,3-tetramethyl uronium hexafluorophosphate methanaminium (HATU) was obtained from Genscript Inc. (Piscataway, NJ). Sulfuric acid, methanol, DMSO, DMF, TFA, isopropyl alcohol, $\mathrm{NH}_{2}-\mathrm{PEG}_{12}-\mathrm{COOH}-\mathrm{tBu}$, diisopropylethylamine (DIPEA), piperidine, $\mathrm{CF}_{3} \mathrm{COOH}, \mathrm{CH}_{2} \mathrm{Cl}_{2}, \mathrm{~K}_{2} \mathrm{CO}_{3}$, tyramine and all other chemical reagents were purchased from Sigma Aldrich. Purecoat Amine 24-well microtiter plates were purchased from BD Biosciences (San Jose, CA). All other cell culture reagents, syringes and disposable items were purchased from VWR (Chicago, IL).

\section{Synthesis of CA IX conjugated near infrared fluorescent dye (Hypoxyfluor) and rhodamine (CA IX-Rhodamine)}

The CA IX ligand was synthesized using previously described methods (7). As shown in scheme 1 , one of the free carboxylic acid groups was protected using concentrated sulfonic acid in methanol and purified with an $83 \%$ yield and $96 \%$ purity. The methylated ligand was then reacted with $\mathrm{NH}_{2}-\mathrm{PEG}_{12}$-t-butyl (76\% yield, $87 \%$ purity) and the resulting compound was deprotected by trifluoroacetic acid with a yield of $87 \%$ and a purity of $84 \%$. For the rhodamine conjugate, (5-((5-aminopentyl)carbamoyl)-2-(6-(dimethylamino)-3(dimethyliminio)-3H-xanthen-9-yl)benzoate hydrochloride) was coupled to the deprotected compound in the presence of EDC.HCl and HOBt in DMSO for 12 hours to yield the final target conjugate named CA IX-Rhodamine. For the near infrared fluorescent dye, the resulting deprotected compound was coupled with tyramine to introduce the phenolic group (70\% yield and 98\% purity), which then was reacted with the near infrared dye (S0456) to afford the final target conjugate, named Hypoxyfluor. The crude product was purified by preparative reverse-phase high-performance liquid chromatography (yield of $48 \%$ and final purity of $90 \%$ ) with a gradient mobile phase consisting of $20 \mathrm{mM}$ ammonium acetate buffer and 5\% to $80 \%$ acetonitrile over $30 \mathrm{~min}$ (xTerra C18; Waters; $10 \mathrm{um} ; 19 \times 250 \mathrm{~mm}$ ). Elution of the conjugate was monitored at $280 \mathrm{~nm}$ and identities of eluted compounds were analyzed by liquid chromatography-mass spectrometry (see supporting information).

\section{Cell culture}

HT-29 human colon cancer cells were cultured in RPMI 1640 medium supplemented with $10 \%$ fetal bovine serum and $1 \%$ penicillin-streptomycin at $37{ }^{\circ} \mathrm{C}$ in a humidified $95 \%$ air$5 \% \mathrm{CO}_{2}$ atmosphere.

\section{Fluorescent microscopy}

HT-29 cells $\left(10^{5}\right)$ were seeded into chambered coverglass plates and allowed to grow to confluence over 48-72 hr. Spent medium was replaced with $0.5 \mathrm{~mL}$ of fresh serum free medium containing $50 \mathrm{nM}$ Hypoxyfluor or CA IX-Rhodamine in the presence or absence of 100-fold excess CA IX inhibitor. After incubation for 1 hour at $37{ }^{\circ} \mathrm{C}$, cells were rinsed three times with $1 \mathrm{~mL}$ of incubation solution to remove unbound fluorescence and $0.5 \mathrm{~mL}$ of fresh medium was added to the wells. Images were acquired using confocal microscopy (FV 
1000, Olympus) for CA IX-Rhodamine and fluorescent microscopy (Nikon 90i) for Hypoxyfluor.

\section{Binding of CAIX-PEG ${ }_{12}$-S0456 conjugate (Hypoxyfluor) to HT-29 cells}

HT-29 cells $\left(10^{5}\right)$ were seeded into 24 -well BD purecoat amine plates and allowed to grow to confluence over 48-72 hr. Spent medium was replaced with $0.5 \mathrm{~mL}$ of fresh medium containing $0.5 \%$ bovine serum albumin, and various concentrations of the dye conjugate alone or the dye conjugate plus 100-fold excess CA IX ligand were added. After incubation for 1 hour at $4{ }^{\circ} \mathrm{C}$, cells were rinsed with incubation solution $(2 \times 1.0 \mathrm{~mL})$ to remove unbound fluorescence and dissolved in $0.5 \mathrm{~mL}$ of $1 \%$ aqueous sodium dodecyl sulfate. Cell associated fluorescence was then measured using an excitation of $745 \mathrm{~nm}$ and emission of $790 \mathrm{~nm}$. All experiments were performed in triplicate. The dissociation constant $\left(\mathrm{K}_{\mathrm{D}}\right)$ was calculated from a plot of cell bound fluorescence (RFU) versus the concentration of fluorescent conjugate added using the program, Graphpad Prism, and assuming a noncooperative single site binding equilibrium.

\section{Animal husbandry}

Athymic female nu/nu mice were purchased from Harlan Laboratories, housed in a sterile environment on a standard 12 hour light-dark cycle and maintained on normal rodent chow. All animal procedures were approved by the Purdue Animal Care and Use Committee in accordance with National Institutes of Health guidelines.

\section{Fluorescence imaging and biodistribution}

Using a 25-gauge needle, six-week-old female nu/nu mice were inoculated subcutaneously in their shoulders with HT-29 cells in RPMI1640 medium $\left(5.0 \times 10^{6}\right.$ cells per mouse). Tumor growth was measured in 2 perpendicular directions every 2 days with a caliper. Tumor volumes were calculated using the formula $0.5 \times \mathrm{L} \times \mathrm{W}^{2}$, where $\mathrm{L}$ is the measurement of the longest axis and $\mathrm{W}$ is the measurement of the axis perpendicular to $\mathrm{L}$. Tumor bearing mice were treated via tail vein injection with different concentrations of dye conjugate in the presence or absence of 100-fold CA IX ligand to block all unoccupied CA IX binding sites ( $\mathrm{n}=3$ for each treatment group). Mice were imaged 4 hours post injection using a Caliper IVIS Lumina II Imaging station coupled to an ISOON5160 Andor Nikon camera equipped with Living Image Software Version 4.0. Image acquisition settings were as follows: lamp level, high; excitation, $745 \mathrm{nM}$; emission, ICG; epi illumination; binning (M) 4; FOV, 12.5; f-stop, 4; acquisition time, $1 \mathrm{~s}$. Ratios of the fluorescence in regions of interest were determined using ImageJ software.

\section{Results}

\section{Synthesis}

A potent inhibitor of CA IX (7) was chosen for use as a targeting ligand for delivery of a near infrared (NIR) dye (S0456) for use in fluorescent guided surgery. As shown in Scheme 1, the CA IX ligand was first coupled to a $\mathrm{PEG}_{12}$ linker via an amide bond, which in turn was conjugated to tyramine via a second amide bond. The activated chloro derivative of the NIR fluorophore, S0456 (46), was then coupled to the tyramine via nucleophilic 
displacement in the presence of base. The final conjugate (CAIX-PEG ${ }_{12}-S 0456$ ) was obtained in a total overall yield of $18.4 \%$, purified by HPLC, and named Hypoxyfluor. The total molecular weight of the conjugate is 2171.54 . The $\lambda_{\mathrm{ex}}=770 \mathrm{~nm}$ and the $\lambda_{\mathrm{em}}=790 \mathrm{~nm}$.

\section{In vitro binding to HT-29 cells}

HT-29 cells that naturally express CA IX were used to determine cancer cell uptake and binding affinity of the newly synthesized conjugate. For this purpose, various concentrations of Hypoxyfluor and a fluorescent rhodamine conjugate (CA IX-rhodamine) were incubated with HT-29 cells for 1 hour at $37{ }^{\circ} \mathrm{C}$ for uptake studies or $4{ }^{\circ} \mathrm{C}$ for binding affinity studies, after which unbound conjugate was removed by washing. Cell associated fluorescence was imaged via fluorescent microscopy for Hypoxyfluor and confocal microscopy for CA IXRhodamine. Additionally, fluorescence was quantitated as described in Methods to determine binding affinity. As shown in Figure 1A and 1B, Hypoxyfluor and CA IXrhodamine binding was seen on both the cell surface and internal endosomes of cultured HT-29 cells. Moreover, Hypoxyfluor binding was found to be saturable with an apparent dissociation constant of $45 \mathrm{nM}$ (Figure 1C). Since the reported $\mathrm{K}_{\mathrm{I}}$ of the unmodified original ligand was $7.8 \mathrm{nM}$ (7), it can be concluded that attachment of the PEG linker and fluorophore only moderately compromises CA IX binding affinity. Importantly, when a 100fold excess of the unconjugated ligand was pre-incubated with the HT-29 cells, most of the Hypoxyfluor or CA IX-Rhodamine binding was competed, demonstrating that the majority of cell uptake was receptor specific.

\section{In vivo imaging and biodistribution}

To determine whether Hypoxyfluor can specifically label CA IX expressing tumors in vivo, mice bearing HT-29 tumor xenografts ( $\mathrm{n}=3$ for each treatment group) were injected via tail vein with 4 nmol of the conjugate and imaged 4 hours later. This time point was chosen as it yielded the greatest contrast in intensity between the tumor and other tissues. As shown in Figure 2, conjugate fluorescence was predominately detected in the tumor 4 hours postinjection. As time went on, overall fluorescence intensity decreased in all tissues and by 8 hours post-injection, the majority of fluorescence was lost from the tumor (see image in Supporting Information). Moreover, when $400 \mathrm{nmol}$ of the original, non-fluorescent ligand was injected together with the $4 \mathrm{nmol}$ of Hypoxyfluor, no fluorescent signal could be detected in the whole animal images, suggesting that tumor cell uptake was also CA IX receptor specific in vivo and therefore, tumor accumulation was not mediated by either nonspecific binding or the enhanced permeability and retention (EPR) effect.

To better assess the accumulation of Hypoxyfluor in nonmalignant tissues, major organs/ tissues were removed and examined for $S 0456$ fluorescence 4 hours post-injection. As shown in Figure 3, fluorescence was apparent in the tumor and kidneys with very little or no signal observed in any other tissues. Similar to whole animal images, little 50456 fluorescence was observed in any tissues when Hypoxyfluor uptake was measured upon concurrent injection of excess unconjugated ligand. For example, the fluorescence intensity in the excised tumor was on average 22 times less in the mice injected with competing ligand. 
Next, a dose escalation study of Hypoxyfluor was performed, where 3,13 and $40 \mathrm{nmol}$ of conjugate were injected via tail vein in HT-29 tumor-bearing mice. As shown in Figure 4, fluorescence was restricted to the tumor when low and intermediate doses were administered. In contrast, following injection of $40 \mathrm{nmol} /$ mouse, nontumor associated fluorescence became apparent in whole body images. Indeed, when major organs and tissues were removed and imaged, high fluorescence was observed in kidneys and additional fluorescence was seen in the liver, suggesting that at high injection doses Hypoxyfluor is still primarily excreted via the kidney, but may be partially cleared through the liver as well (Figure 5).

\section{Discussion}

Advances in real-time optical imaging for surgery have led to the creation of fluorescent NIR dyes that enable differentiation of cancerous from normal tissues (47). However, despite the availability of ligand-targeted NIR dyes that bind the epidermal growth factor receptor (48), folate receptor alpha (49), CCK2R (50) and PSMA (51), the majority of human cancers still cannot be imaged with a tumor-targeted fluorescent dye. Several reports of CA IXtargeted fluorescent and radioimaging agents have shown the utility of carbonic anhydrase IX targeting ligands for visualization of cancers $(38,52,53)$. Using a different high affinity CA IX ligand, we demonstrate here that a novel CA IX-targeted NIR dye that can illuminate CA IX over-expressing tumors with similar or better results than previous CA IX-fluorescent conjugates. Because CA IX mRNA is present in human cancers of the cervix, esophagus, pancreas, bladder, breast, kidney, stomach, endometrium, ovary, colorectum, lung, liver and testes at levels similar to its expression in HT-29 cells (unpublished data), we anticipate that CA IX targeted fluorescent dyes will prove useful in a large number of cancer surgeries.

One of the properties that contributes to the value of any tumor-targeted imaging agent is the ability of the fluorescent dye to internalize into the cancer cell. Upon endocytosis, the imaging agent can then become trapped within the target cell, preventing its diffusion into adjacent healthy tissues. As a consequence, images obtained with internalizing conjugates are commonly much sharper than images collected with noninternalizing dyes. Such high definition can be important when malignant lesions must be resected that i) abut critical healthy tissues (e.g. major nerves, blood vessels, ducts, etc.), ii) display highly irregular surface topographies, or iii) contain only a few malignant cells. Importantly, as shown in Figure 1, Hypoxyfluor is aggressively internalized by CA IX in HT-29 cells.

Three other important qualities that should be considered for any intra-operative fluorescent imaging agent are its: 1) fluorescence quantum yield, 2) relative uptake in healthy tissues, and 3) rate of clearance from receptor-negative tissues. Its uptake in normal tissues at reasonable dosing concentrations is minimal except for the kidneys, allowing for imaging of many solid tumors with little healthy tissue background fluorescence. And clearance from receptor-negative tissues is rapid, likely permitting injection of the fluorescent dye during preparation of the patient for surgery. Taken together, Hypoxyfluor would seem to warrant further exploration as a tumor-targeted fluorescent dye for fluorescence guided surgery in humans. 


\section{Supplementary Material}

Refer to Web version on PubMed Central for supplementary material.

\section{Acknowledgments}

The authors gratefully acknowledge the campus-wide mass spectroscopy facility and support from the Purdue University Center for Cancer Research, P30CA023168. This work was supported by a grant from Endocyte Inc.

\section{References}

1. Noman MZ, Hasmim M, Messai Y, Terry S, Kieda C, Janji B, Chouaib S. Hypoxia: a key player in anti-tumor immune response. A review in the Theme: Cellular Responses to Hypoxia. Am J Physiol Cell Physiol. 2015; 309(1):C569-C579. [PubMed: 26310815]

2. Scanion SE, Glazer PM. Multifaceted control of DNA repair pathways by the hypoxic tumor microenvironment. DNA Repair (Amst). 2015; 32:180-189. [PubMed: 25956861]

3. Span PN, Bussink J. Biology of hypoxia. Semin Nucl Med. 2015; 45(2):101-109. [PubMed: 25704383]

4. Harris BH, Barberis A, West CM, Buffa FM. Gene Expression Signatures as Biomarkers of Tumour Hypoxia. Clin Oncol (R Coll Radiol). 2015; 27(10):547-560. [PubMed: 26282471]

5. Ramachandran S, Ient J, Gottgens EL, Krieg AJ, Hammond EM. Epigenetic therapy for solid tumors: highlighting the impact of tumor hypoxia. Genes (Basel). 2015; 6(4):935-956. [PubMed: 26426056]

6. Pastorek J, Pastorekova S. Hypoxia-induced carbonic anhydrase IX as a target for cancer therapy: from biology to clinical use. Semin Cancer Biol. 2015; 31:52-64. [PubMed: 25117006]

7. Rami M, Winum JY, Innocenti A, Montero JL, Scozzafava A, Supuran CT. Carbonic anhydrase inhibitors: copper(II) complexes of polyamino-polycarboxylamido aromatic/heterocyclic sulfonamides are very potent inhibitors of the tumor-associated isoforms of IX and XII. Bioorg Med Chem Lett. 2008; 18(2):836-841. [PubMed: 18042384]

8. Hoskin PJ, Sibtain A, Daley FM, Wilson GD. GLUT1 and CAIX as intrinsic markers of hypoxia in bladder cancer: relationship with vascularity and proliferation as predictors of outcome of ARCON. Br J Cancer. 2003; 89:1290-1297. [PubMed: 14520462]

9. Klatte T, Seligson DB, Rao JY, Yu H, de Martino M, Kawaoka K, Wong SG, Belldegrun AS, Pantuck AJ. Carbonic anhydrase IX in bladder cancer: a diagnostic, prognostic, and therapeutic molecular marker. Cancer. 2009; 115:1448-1458. [PubMed: 19195047]

10. Nordfors K, Haapasalo J, Korja M, Niemela A, Laine J, Parkkila AK, Pastorekova S, Pastorek J, Waheed A, Sly WS, Parkkila S, Haapasalo H. The tumour-associated carbonic anhydrases CA II, CA IX and CA XII in a group of medulloblastomas and supratentorial primitive neuroectodermal tumours: an association of CA IX with poor prognosis. BMC Cancer. 2010; 10:148. [PubMed: 20398423]

11. Proescholdt MA, Merrill MJ, Stoerr EM, Lohmeier A, Pohl F, Brawanski A. Function of carbonic anhydrase IX in glioblastoma multiforme. Neuro Oncol. 2012; 14:1357-1366. [PubMed: 23074198]

12. Haapasalo JA, Nordfors KM, Hilvo M, Rantala IJ, Soini Y, Parkkila AK, Pastorekova S, Pastorek J, Parkkila SM, Haapasalo HK. Expression of carbonic anhydrase IX in astrocytic tumors predicts poor prognosis. Clin Cancer Res. 2006; 12:473-477. [PubMed: 16428489]

13. Chia SK, Wykoff CC, Watson PH, Han C, Leek RD, Pastorek J, Gatter KC, Ratcliffe P, Harris AL. Prognostic significance of a novel hypoxia-regulated marker, carbonic anhydrase IX, in invasive breast carcinoma. J Clin Oncol. 2001; 19:3660-3668. [PubMed: 11504747]

14. Trastour C, Benizri E, Ettore F, Ramaioli A, Chamorey E, Pouyssegur J, Berra E. HIF-1alpha and CA IX staining in invasive breast carcinomas: prognosis and treatment outcome. Int J Cancer. 2007; 120:1451-1458. [PubMed: 17245699]

15. Tan EY, Yan M, Campo L, Han C, Takano E, Turley H, Candiloro I, Pezzella F, Gatter KC, Millar EK, O'Toole SA, McNeil CM, Crea P, Segara D, Sutherland RL, Harris AL, Fox SB. The key 
hypoxia regulated gene CAIX is upregulated in basal-like breast tumours and is associated with resistance to chemotherapy. Br J Cancer. 2009; 100:405-411. [PubMed: 19165203]

16. Hussain SA, Ganesan R, Reynolds G, Gross L, Stevens A, Pastorek J, Murray PG, Perunovic B, Anwar MS, Billingham L, James ND, Spooner D, Poole CJ, Rea DW, Palmer DH. Hypoxiaregulated carbonic anhydrase IX expression is associated with poor survival in patients with invasive breast cancer. Br J Cancer. 2007; 96:104-109. [PubMed: 17213826]

17. Neumeister VM, Sullivan CA, Lindner R, Lezon-Geyda K, Li J, Zavada J, Martel M, Glazer PM, Tuck DP, Rimm DL, Harris L. Hypoxia-induced protein CAIX is associated with somatic loss of BRCA1 protein and pathway activity in triple negative breast cancer. Breast Cancer Res Treat. 2012; 136:67-75. [PubMed: 22976806]

18. Loncaster JA, Harris AL, Davidson SE, Logue JP, Hunter RD, Wycoff CC, Pastorek J, Ratcliffe PJ, Stratford IJ, West CM. Carbonic anhydrase (CA IX) expression, a potential new intrinsic marker of hypoxia: correlations with tumor oxygen measurements and prognosis in locally advanced carcinoma of the cervix. Cancer Res. 2001; 61:6394-6399. [PubMed: 11522632]

19. Kim JY, Shin HJ, Kim TH, Cho KH, Shin KH, Kim BK, Roh JW, Lee S, Park SY, Hwang YJ, Han IO. Tumor-associated carbonic anhydrases are linked to metastases in primary cervical cancer. $\mathrm{J}$ Cancer Res Clin Oncol. 2006; 132:302-308. [PubMed: 16416108]

20. Lee S, Shin HJ, Han IO, Hong EK, Park SY, Roh JW, Shin KH, Kim TH, Kim JY. Tumor carbonic anhydrase 9 expression is associated with the presence of lymph node metastases in uterine cervical cancer. Cancer Sci. 2007; 98:329-333. [PubMed: 17233814]

21. Woelber L, Kress K, Kersten JF, Choschzick M, Kilic E, Herwig U, Lindner C, Schwarz J, Jaenicke F, Mahner S, Milde-Langosch K, Mueller V, Ihnen M. Carbonic anhydrase IX in tumor tissue and sera of patients with primary cervical cancer. BMC Cancer. 2011; 11:12. [PubMed: 21223596]

22. Saarnio J, Parkkila S, Parkkila AK, Haukipuro K, Pastorekova S, Pastorek J, Kairaluoma MI, Karttunen TJ. Immunohistochemical study of colorectal tumors for expression of a novel transmembrane carbonic anhydrase, MN/CA IX, with potential value as a marker of cell proliferation. Am J Pathol. 1998; 153:279-285. [PubMed: 9665489]

23. Korkeila E, Talvinen K, Jaakkola PM, Minn H, Syrjanen K, Sundstrom J, Pyrhonen S. Expression of carbonic anhydrase IX suggests poor outcome in rectal cancer. Br J Cancer. 2009; 100:874-880. [PubMed: 19240720]

24. Niemela AM, Hynninen P, Mecklin JP, Kuopio T, Kokko A, Aaltonen L, Parkkila AK, Pastorekova S, Pastorek J, Waheed A, Sly WS, Orntoft TF, Kruhoffer M, Haapasalo H, Parkkila S, Kivela AJ. Carbonic anhydrase IX is highly expressed in hereditary nonpolyposis colorectal cancer. Cancer Epidemiol Biomarkers Prev. 2007; 16:1760-1766. [PubMed: 17855694]

25. Chen J, Rocken C, Hoffmann J, Kruger S, Lendeckel U, Rocco A, Pastorekova S, Malfertheiner P, Ebert MP. Expression of carbonic anhydrase 9 at the invasion front of gastric cancers. Gut. 2005; 54:920-927. [PubMed: 15951534]

26. Hoogsteen IJ, Marres HA, Wijffels KI, Rijken PF, Peters JP, van den Hoogen FJ, Oosterwijk E, van der Kogel AJ, Kaanders JH. Colocalization of carbonic anhydrase 9 expression and cell proliferation in human head and neck squamous cell carcinoma. Clin Cancer Res. 2005; 11:97106. [PubMed: 15671533]

27. De Schutter H, Landuyt W, Verbeken E, Goethals L, Hermans R, Nuyts S. The prognostic value of the hypoxia markers CA IX and GLUT 1 and the cytokines VEGF and IL 6 in head and neck squamous cell carcinoma treated by radiotherapy +/- chemotherapy. BMC Cancer. 2005; 5:42. [PubMed: 15847702]

28. Koukourakis MI, Bentzen SM, Giatromanolaki A, Wilson GD, Daley FM, Saunders MI, Dische S, Sivridis E, Harris AL. Endogenous markers of two separate hypoxia response pathways (hypoxia inducible factor 2 alpha and carbonic anhydrase 9) are associated with radiotherapy failure in head and neck cancer patients recruited in the CHART randomized trial. J Clin Oncol. 2006; 24:727735. [PubMed: 16418497]

29. Swinson DE, Jones JL, Richardson D, Wykoff C, Turley H, Pastorek J, Taub N, Harris AL, O'Byrne KJ. Carbonic anhydrase IX expression, a novel surrogate marker of tumor hypoxia, is associated with a poor prognosis in non-small-cell lung cancer. J Clin Oncol. 2003; 21:473-482. [PubMed: 12560438] 
30. Kim SJ, Rabbani ZN, Dewhirst MW, Vujaskovic Z, Vollmer RT, Schreiber EG, Oosterwijk E, Kelley MJ. Expression of HIF-1alpha, CA IX, VEGF, and MMP-9 in surgically resected non-small cell lung cancer. Lung Cancer. 2005; 49:325-335. [PubMed: 15935515]

31. Ilie M, Mazure NM, Hofman V, Ammadi RE, Ortholan C, Bonnetaud C, Havet K, Venissac N, Mograbi B, Mouroux J, Pouyssegur J, Hofman P. High levels of carbonic anhydrase IX in tumour tissue and plasma are biomarkers of poor prognostic in patients with non-small cell lung cancer. $\mathrm{Br}$ J Cancer. 2010; 102:1627-1635. [PubMed: 20461082]

32. Choschzick M, Oosterwijk E, Muller V, Woelber L, Simon R, Moch H, Tennstedt P. Overexpression of carbonic anhydrase IX (CAIX) is an independent unfavorable prognostic marker in endometrioid ovarian cancer. Virchows Arch. 2011; 459:193-200. [PubMed: 21691815]

33. Juhasz M, Chen J, Lendeckel U, Kellner U, Kasper HU, Tulassay Z, Pastorekova S, Malfertheiner P, Ebert MP. Expression of carbonic anhydrase IX in human pancreatic cancer. Aliment Pharmacol Ther. 2003; 18:837-846. [PubMed: 14535878]

34. Maxwell PH, Wiesener MS, Chang GW, Clifford SC, Vaux EC, Cockman ME, Wykoff CC, Pugh $\mathrm{CW}$, Maher ER, Ratcliffe PJ. The tumour suppressor protein VHL targets hypoxia-inducible factors for oxygen-dependent proteolysis. Nature. 1999; 399:271-275. [PubMed: 10353251]

35. Liao SY, Aurelio ON, Jan K, Zavada J, Stanbridge EJ. Identification of the MN/CA9 protein as a reliable diagnostic biomarker of clear cell carcinoma of the kidney. Cancer Res. 1997; 57:28272831. [PubMed: 9230182]

36. Muriel Lopez C, Esteban E, Berros JP, Pardo P, Astudillo A, Izquierdo M, Crespo G, Sanmamed M, Fonseca PJ, Martinez-Camblor P. Prognostic factors in patients with advanced renal cell carcinoma. Clin Genitourin Cancer. 2012; 10:262-270. [PubMed: 22959659]

37. Sneddon D, Poulsen SA. Agents described in the Molecular Imaging and Contrast Agent Database for imaging carbonic anhydrase IX expression. J Enzyme Inhib Med Chem. 2014; 29(5):753-763. [PubMed: 24506208]

38. Tafreshi NK, Lloyd MC, Bui MM, Gillies RJ, Morse DL. Carbonic anhydrase IX as an imaging and therapeutic target for tumors and metastases. Subcell Biochem. 2014; 75:221-254. [PubMed: 24146382]

39. Kelderhouse LE, Chelvam V, Wayua C, Mahalingam S, Poh S, Kularatne SA, Low PS. Development of tumor-targeted near infrared probes for fluorescence guided surgery. Bioconjug Chem. 2013; 24(6):1075-1080. [PubMed: 23642154]

40. Okusanya OT, DeJesus EM, Jiang JX, Judy RP, Venegas OG, Deshpande CG, Heitjan DF, Nie S, Low PS, Singhal S. Intraoperative molecular imaging can identify lung adenocarcinomas during pulmonary resection. J Thorac Cardiovasc Surg. 2015; 150(1):28-35. [PubMed: 26126457]

41. Satou S, Ishizawa T, Masuda K, Kaneko J, Aoki T, Sakamoto Y, Hasegawa K, Sugawara Y, Kokudo N. Indocyanine green fluorescent imaging for detecting extrahepatic metastasis of hepatocellular carcinoma. J Gastroenterol. 2013; 48(10):1136-1143. [PubMed: 23179608]

42. Yokoyama N, Otani T, Hashidate H, Maeda C, Katada T, Sudo N, Manabe S, Ikeno Y, Toyoda A, Katayanagi N. Real-time detection of hepatic micrometastases from pancreatic cancer by intraoperative fluorescence imaging: preliminary results of a prospective study. Cancer. 2012; 118(11):2813-2819. [PubMed: 21990070]

43. van der Vorst JR, Schaafsma BE, Hutteman M, Verbeek FP, Liefers GJ, Hartgrink HH, Smit VT, Löwik CW, van de Velde CJ, Frangioni JV, Vahrmeijer AL. Near-infrared fluorescence-guided resection of colorectal liver metastases. Cancer. 2013; 119(118):3411-3418. [PubMed: 23794086]

44. Hentschel SJ, Sawaya R. Optimizing outcomes with maximal surgical resection of malignant gliomas. Cancer Control. 2003; 10(2):109-114. [PubMed: 12712005]

45. Bucci MK, Maity A, Janss AJ, Belasco JB, Fisher MJ, Tochner ZA, Rorke L, Sutton LN, Phillips PC, Shu HK. Near complete surgical resection predicts a favorable outcome in pediatric patients with nonbrainstem, malignant gliomas: results from a single center in the magnetic resonance imaging era. Cancer. 2004; 101(4):817-824. [PubMed: 15305415]

46. Lee H, Mason JC, Achilefu S. Heptamethine cyanine dyes with a robust C-C bond at the central position of the chromophore. J Org Chem. 2006; 71(20):7862-7865. [PubMed: 16995699]

47. Bu L, Shen B, Cheng Z. Fluorescent imaging of cancerous tissues for targeted surgery. Adv Drug Deliv Rev. 2014; 76:21-38. [PubMed: 25064553] 
48. Warram JM, de Boer E, Korb M, Hartman Y, Kovar J, Marert JM, Gillespie GY, Rosenthal EL. Fluorescence-guided resection of experimental malignant glioma using cetuximab-IRDye 800CW. Br J Neurosurg. 2015; 15:1-9.

49. Okusanya OT, DeJesus EM, Jiang JX, Judy RP, Venegas OG, Deshpande CG, Heitjan DF, Nie S, Low PS, Singhal S. Intraoperative molecular imaging can identify lung adenocarcinomas during pulmonary resection. J Thorac Cardiovasc Surg. 2015; 150(1):28-35. [PubMed: 26126457]

50. Wayua C, Low PS. Evaluation of a cholecystokinin 2 receptor-targeted near-infrared dye for fluorescence-guided surgery of cancer. Mol Pharm. 2014; 11(2):468-476. [PubMed: 24325469]

51. Kelderhouse LE, Chelvam V, Wayua C, Mahalingam S, Poh S, Kularatne SA, Low PS. Development of tumor-targeted near infrared probes for fluorescence guided surgery. Bioconjug Chem. 2013; 24(6):1075-1080. [PubMed: 23642154]

52. Groves K, Bao B, Zhang J, Handy E, Kennedy P, Cuneo G, Supuran CT, Yared W, Peterson JD, Rajopadhye M. Synthesis and evaluation of near-infrared fluorescent sulfonamide derivatives for imaging of hypoxia-induced carbonic anhydrase IX expression in tumors. Bioorg Med Chem Lett. 2012; 22(1):653-657. [PubMed: 22079760]

53. Bao B, Groves K, Zhang J, Handy E, Kennedy P, Cuneo G, Supuran CT, Yared W, Rajopadhye M, Peterson JD. In vivo imaging and quantification of carbonic anhydrase IX expression as an endogenous biomarker of tumor hypoxia. PLoS One. 2012; 7(11):e50860. [PubMed: 23226406] 

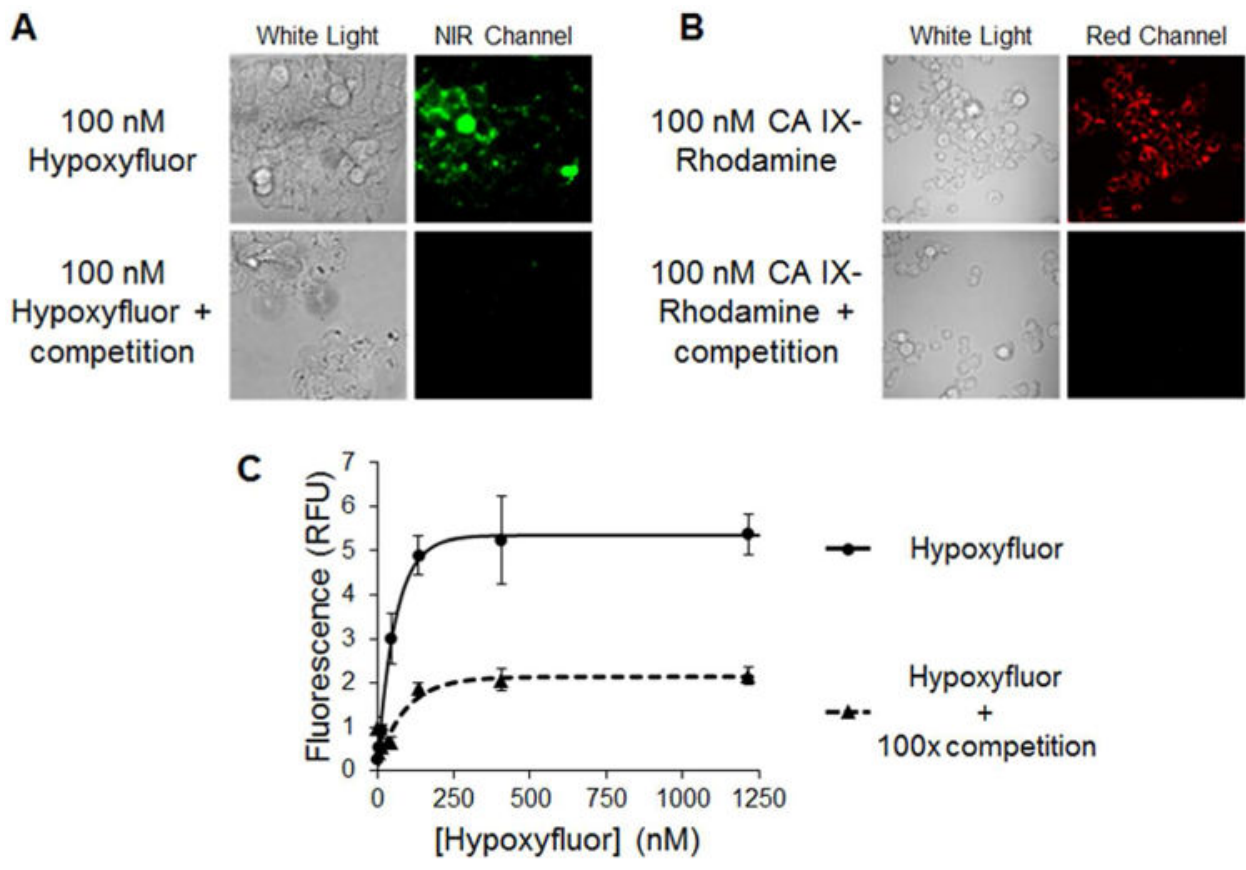

Figure 1.

Binding of Hypoxyfluor and CA IX-targeted rhodamine to HT-29 cells. A) HT-29 cells were incubated with $100 \mathrm{nM}$ Hypoxyfluor in the presence or absence of 100-fold excess of the CA IX inhibitor. After washing, the cell-associated fluorescence was imaged using a nonconfocal fluorescence microscope that could be excited at $747 \mathrm{~nm}$; i.e. the wavelength where the NIR dye absorbs. Because the emitted light is not visible to the eye, the image is false colored green. B) HT-29 cells were similarly incubated with $100 \mathrm{nM} \mathrm{CA} \mathrm{IX-targeted}$ rhodamine in the presence or absence of 100-fold excess CA IX inhibitor. After washing, the cell-associated fluorescence was imaged by confocal microscopy. C) HT-29 cells were incubated with various concentrations of Hypoxyfluor in the presence or absence of 100-fold excess CA IX inhibitor. After washing, the remaining fluorescence was quantitated by fluorescence spectroscopy. Error bars represent standard deviation. 
4 nmol Hypoxyfluor

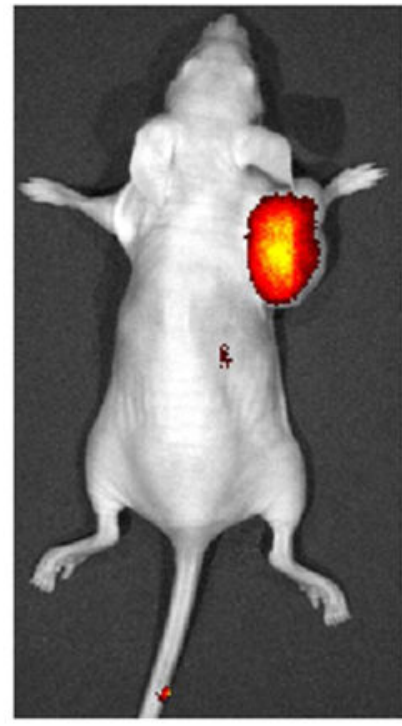

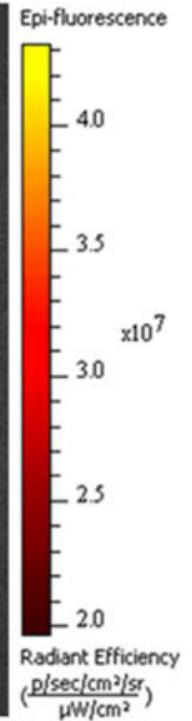

\section{$4 \mathrm{nmol}$ Hypoxyfluor \\ $+$ \\ $400 \mathrm{nmol}$ competition}

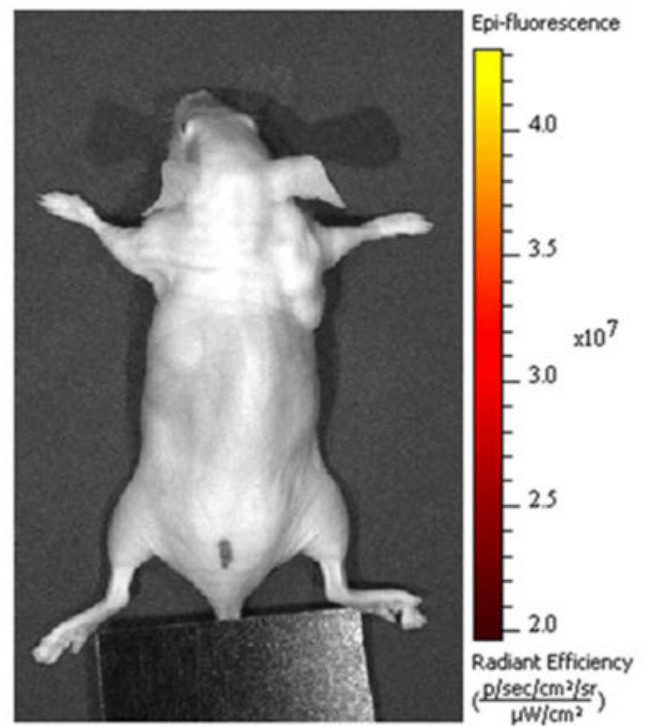

Figure 2.

Representative images of Hypoxyfluor treated HT-29 tumor bearing mice. Mice bearing HT-29 tumors were injected via tail vein with 4 nmol Hypoxyfluor alone or in combination with 100-fold excess CA IX inhibitor ( $n=3$ for each treatment group). Fluorescence images were acquired 4 hours post injection. 
4 nmol Hypoxyfluor

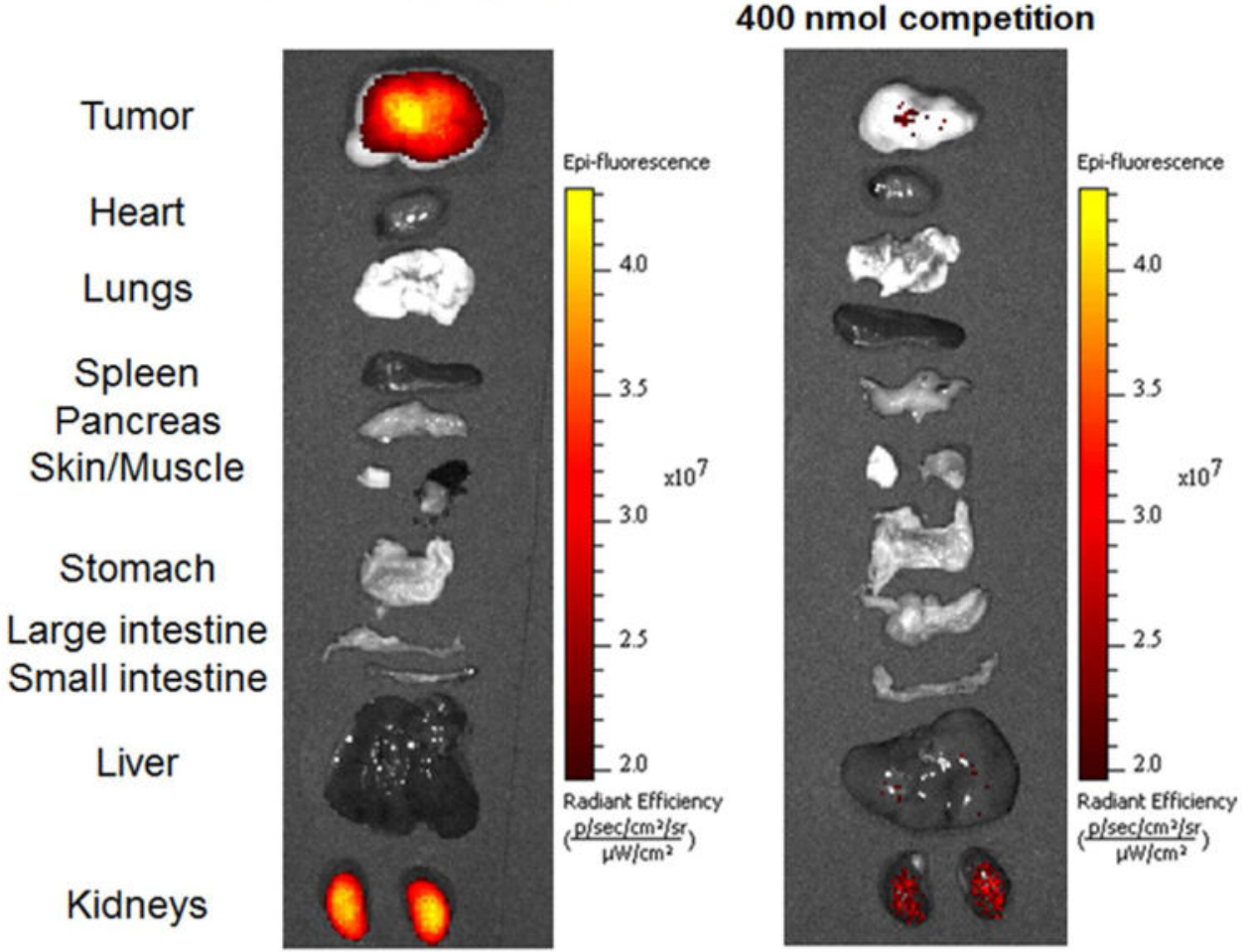

Figure 3.

Accumulation of Hypoxyfluor in internal tissues and organs of mice from Figure 2. Tissues and organs were excised after whole animal imaging and the fluorescence images of the isolated tissues were acquired. 

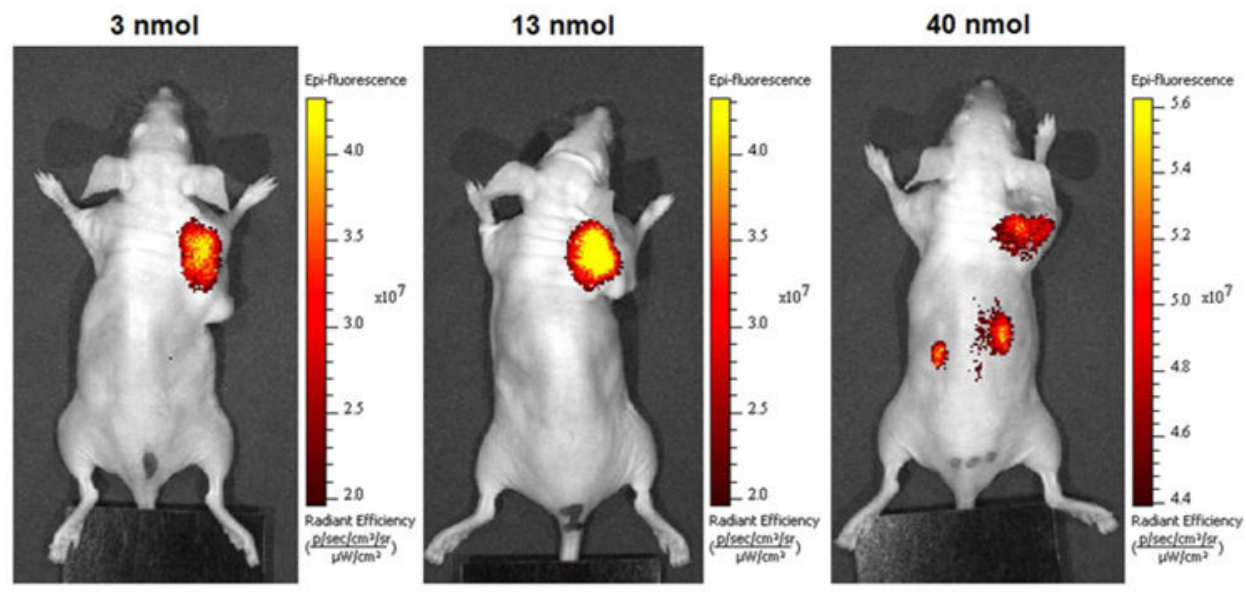

Figure 4.

Representative in vivo images of HT-29 tumor-bearing mice treated with increasing doses of Hypoxyfluor ( $\mathrm{n}=3$ for each treatment group). Mice bearing HT-29 tumors were injected via tail vein with the indicated concentrations of Hypoxyfluor and fluorescence images were acquired 4 hours post injection. 


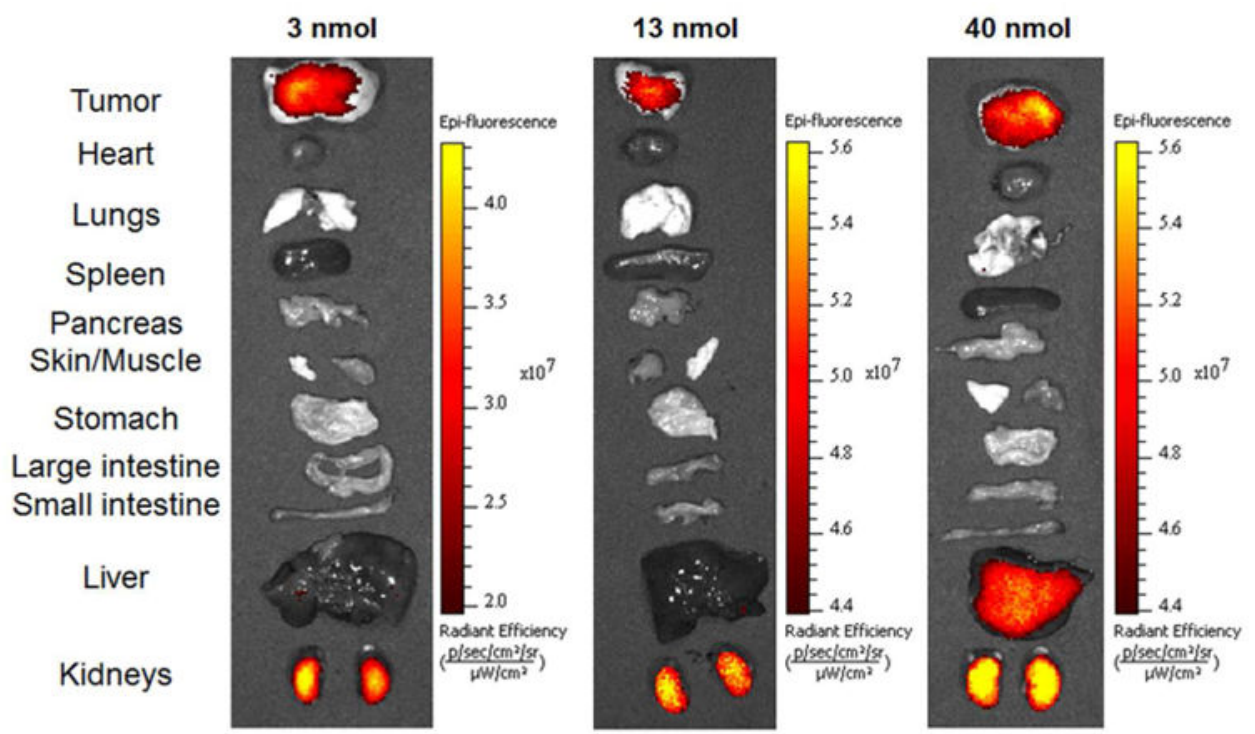

Figure 5.

Accumulation of Hypoxyfluor in internal tissues and organs of mice from Figure 4. Tissues and organs were excised after whole animal imaging and the fluorescence images of the isolated tissues were acquired. 

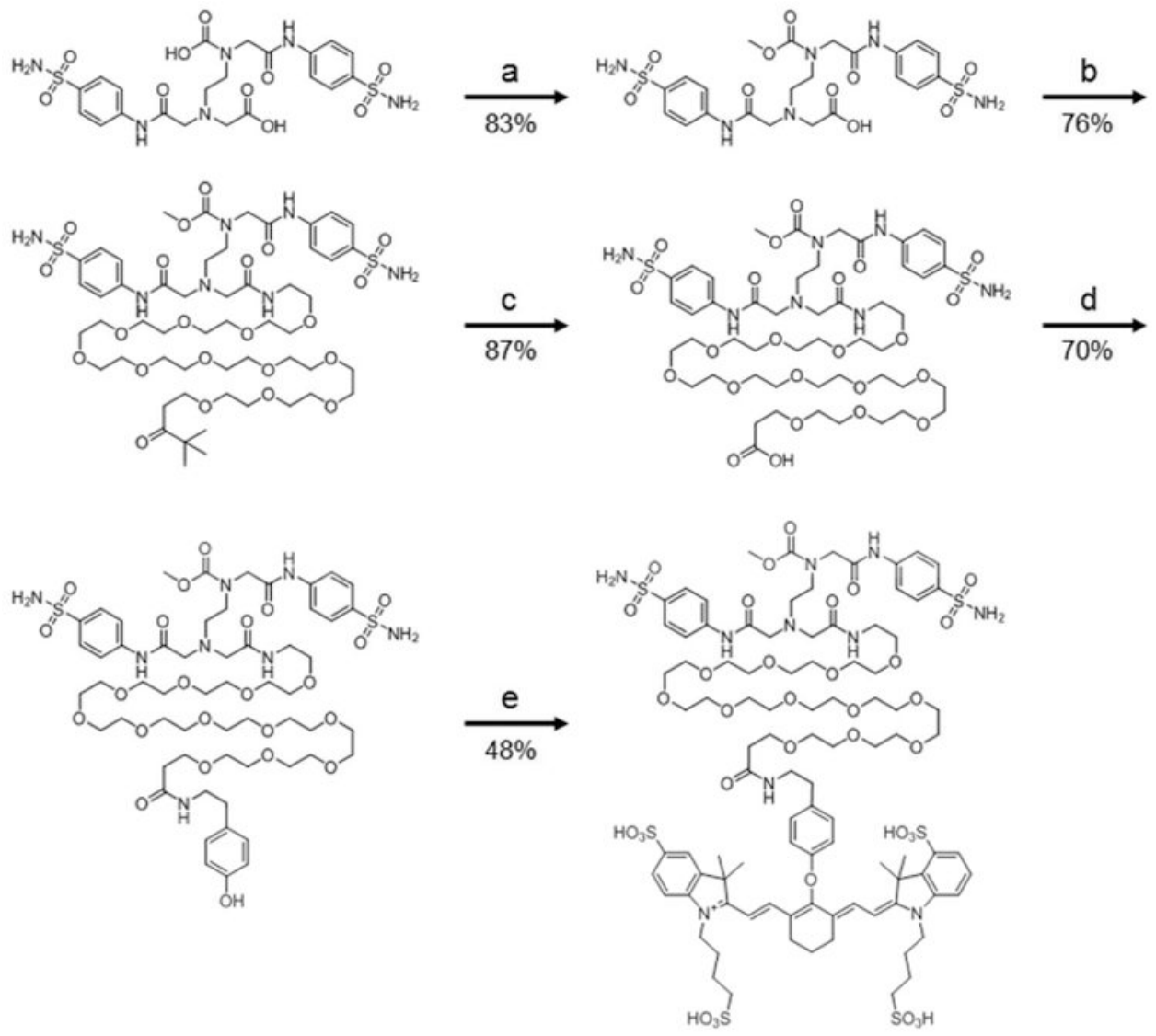

Scheme 1.

Synthesis of CAIX near infrared probe CAIX-PEG ${ }_{12}-\mathrm{S}_{0456}$. Reagents and conditions: a) $\mathrm{H}_{2} \mathrm{SO}_{4}$ in $\mathrm{CH}_{3} \mathrm{OH}, 4$ hr. b) $\mathrm{NH}_{2}-\mathrm{PEG}_{12}-\mathrm{COOH}$-tBu, HATU, DIPEA, DMSO, 24 hr. c) $\mathrm{CF}_{3} \mathrm{COOH}, \mathrm{CH}_{2} \mathrm{Cl}_{2}, 4$ hr. d) Tyramine, HATU, DIPEA, DMSO, 24 hr. e) $\mathrm{K}_{2} \mathrm{CO}_{3}$, DMSO, S0456 $3 \mathrm{hr}$. The resulting compound, CAIX-PEG $12-\mathrm{S} 456$ was named Hypoxyfluor. 